\title{
Protein Patterns in Arbuscular Mycorrhizal Roots and Non-Mycorrhizal Roots of Oil Palm Seedling
}

\author{
HAPPY WIDIASTUTI**, NAMPIAH SUKARNO ${ }^{2}$, AND LATIFAH KOSIM DARUSMAN²
}

\begin{abstract}
${ }^{1}$ Balai Penelitian Bioteknologi Perkebunan Indonesia, Jalan Taman Kencana No. 1, Bogor 16151, Indonesia
${ }^{2}$ Faculty of Mathematics and Natural Sciences, Institut Pertanian Bogor, Darmaga Campus, Bogor 16680, Indonesia
\end{abstract}

\begin{abstract}
A comparison of the protein patterns in root extracts from none mycorrhizal and mycorrhizal oil palm roots has been made. The polypeptides were analyzed every three weeks up to 11 weeks. A factorial design of fungi species (no mycorrhizal, Acaulospora tuberculata, Gigaspora margarita) and with or without fertilizer was assessed. The result showed that specific polypeptides were detected in primary and secondary roots. In unfertilized oil palm root, a $60 \mathrm{kDa}$ polypeptide was detected while it was abcent in fertilized root. Inoculation of $A$. tuberculata with the addition of fertilizer application yielded a specific $26.7 \mathrm{kDa}$ polypeptide in primary root on the 11th week after inoculation. A specific $64.2 \mathrm{kDa}$ polypeptide of G. margarita was detected in unfertilized secondary root also on the 11th week.
\end{abstract}

Key words: polypeptide, Elaeis guineensis, Acaulospora tuberculata, Gigaspora margarita, fertilizer

Arbuscular mycorrhizal obligate biothrop fungi that form mutualistic symbiosis with many of the important agricultural plants such as palm. The formation and function of arbuscular mycorrhiza (AM) induced considerable morphological, physiological, biochemical, and molecular changes for both the host and the symbion (Samra et al. 1997). These changes are presumably the result of complex sequence of interactions between the fungus and the plant's roots.

As in the microbe and plant interactions, regulation of these interactions requires a continuous exchange of signals between both partners, which when perceived through the corresponding receptors would induce a cascade of events, leading to changes in the expression of certain genes (Benabdellah et al. 2000). Pacovsky (1989) reported that during the early infection there are specific polypeptides. The results showed that the quantity and quality of plant protein shifted in response to the physiological changes resulting from infection by $\mathrm{N}_{2}$ fixing bacteria or by endomycorrhizal fungi. Moreover, Samra et al. (1997) showed that there were 12 polypeptides in the mycorrhiza compatible to pea genotypes which were never observed in root extract from the mycorrhiza resistant mutant. The induction and accumulation of these polypeptides seem to be more correlated to the establishment of the functional symbiosis than to the recognition stage and apresorium formation. Ferrol et al. (2002) showed that the expression of plasma membrane $\mathrm{H}^{+}$-ATPase genes was regulated differentially in leaves and root both in wild type and mycorrhiza defective tomato plants. Analysis of 2D-PAGE gels revealed that AM colonization induced changes in protein synthesis and the sequence of polypeptide showed a 75\% identity with the Nterminal sequence of the $69 \mathrm{kDa}$ catalytic subunit of the vacuolar type $\mathrm{H}^{+}$-ATPase of plants (Benabdellah et al. 2000).

Interaction between host and fungi in AM fungi symbiosis with oil palm has never been studied extensively. Understanding the mechanism of interaction is important and necessary in order to get more benefit from the symbiosis

*Corresponding author, Phone: +62-251-324048, Fax: +62-251-328516, E-mail: happywidiastuti@yahoo.com mechanism. Therefore, it is a necessity to see the changes and gene expression involved in the infection process of the symbion. The ability to quantify protein involved in specific mycorrhizal symbiosis could be used to examine the changes in roots which were colonized with AM fungi.

The effect of AM fungi symbiosis for the growth and nutrient absorption of oil palm has been reported before. However, the physiology of oil palm, especially the root's polypeptides during the early infection, was never been reported. Understanding the molecular and genetic basis of the plant-fungus interaction in a functional AM symbiotic system is required for the identification of gene and it's gene products involved in this process. In this paper we used SDS PAGE to study the effect of AM colonization upon the oil palm polypeptide pattern. Two compatible AM fungi species were used in this work.

\section{MATERIALS AND METHODS}

Biological Material and Experimental Design. Plant material used were germinated oil palm of Dura X Pisifera from the Indonesian Oil Palm Research Institute. Acidic soil from Cikopomayak, West Java was used as planting medium (sterilized $3 \times 8$ hours intermitted overnight at $105^{\circ} \mathrm{C}$ ). Spores and infected root fragments were used as inoculant raised on P. phaseoloides plants grown in a glasshouse.

The experimental design used was a factorial complete blocked randomized design. Two treatments assessed were AM fungi species (Acaulospora tuberculata and Gigaspora margarita) and fertilizer (with and without fertilizer). These were used as the samples treatment. The dose of AM fungi inoculant followed the report Widiastuti et al. (2002), while the uninoculated treatment fertilizet as dose was recommended by Lubis (1992).

Growth Conditions. Oil palms seeds were germinated in sterilized sand until they were 3-months-old. At the same time, the preparation of fresh inoculant was done by inoculating Pueraria phaseoloides with AM fungi. P. phaseoloides was grown in $60 \mathrm{~cm} \times 60 \mathrm{~cm}$ sized polybags 
(10 kg absolute dried soil) without a hole containing sterilized acidic soil from Cikopomayak. The oil palm was inoculated with AM fungi by transferring to polybag. The plants were watered with pre-boiled water. Plant harvesting was conducted at 3, 5, 8, and 11 weeks after inoculation. Roots were washed and observed for the AM infection, and analyzed for the polypeptide. A part of a root was sampled to determine the percentage of fungal colonization (Koske and Gemma 1989). The remaining root material was frozen at $-20^{\circ} \mathrm{C}$ before extraction for protein analysis.

Harvesting Procedure and Sampling. Three plants from each treatment were taken and the roots were washed carefully with tap water and weighed for shoot and root of the plant. Roots were pooled to make the root samples. Primary and secondary roots were separately analyzed.

Protein Extraction. Freshly harvested oil palm roots were carefully cleansed in deionized water, weighed, and ground into fine powder in liquid nitrogen. Subsequently the proteins were extracted. The protein content was determined by the Bradford assay (Bradford 1976) and bovine serum albumin (BSA) was used as the standard (Samra et al. 1997).

Gel Electrophoresis and Staining. Sodium-dodecylsulfate-polyacrilamide-gel- electrophoresis (SDS PAGE) was performed as described Laemmli (1970). As much as $30 \mathrm{uM}$ protein was injected into the gel electrophoresis. Gels were stained using the silver staining method (Oakley et al. 1980). Molecular weight of proteins were determined by using a commercial molecular weight marker kit (Bio-Red, Munich Germany).

\section{RESULTS}

Development of AM Fungal Infection. Observation showed that the AM fungi was absent in the uninoculated treatment while it was present in the inoculated plant. In the unfertilized treatment, AM fungi infection was smaller compared to fertilized oil palm seedlings both in $A$. tuberculata and G. margarita (Figure 1). In addition, there were differences of infection pattern between $A$. tuberculata and G. margarita. A. tuberculata infection was slower compared to G. margarita (Widiastuti 2004). In addition, the results showed that AM fungi infection in secondary root was higher compared to those in primary root (Figure 1 and 2). Generally, the enhancement of AM fungi infection in secondary roots was higher after three weeks inoculation, while in primary roots the higher infection was found five weeks after inoculation, especially in G. margarita. However, the results showed that fertilizer enhanced AM fungi infection.

Polypeptide Pattern. The polypeptide pattern in inoculated root was slightly different compared to the uninoculated one. The same result was found between the fertilized and unfertilized oil palm roots. Fertilizer also affected the root polypeptide pattern of inoculated seedling as well as uninoculated seedling.

In general, polypeptide patterns of oil palm root in 3, 5, 8, and 11 th week after inoculation were slightly different between treatment both in primary and secondary roots. However, there were only some polypeptides which appeared to be specific. SDS PAGE analysis of primary root in 11th

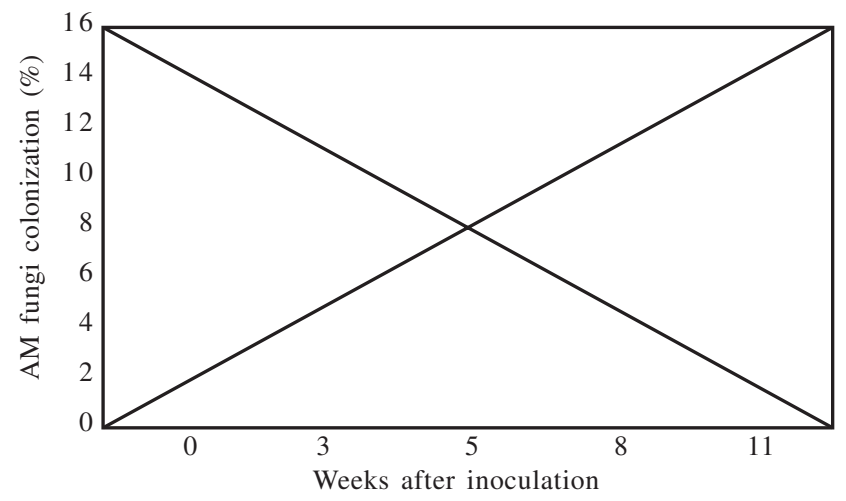

Figure 1 AM fungi colonization in primary root of oil palm. $\checkmark$ A.tuberculata without fertilizer, A. tuberculata with fertilizer,
with fertilizer). G. margarita without fertilizer, $\square$ G. margarita

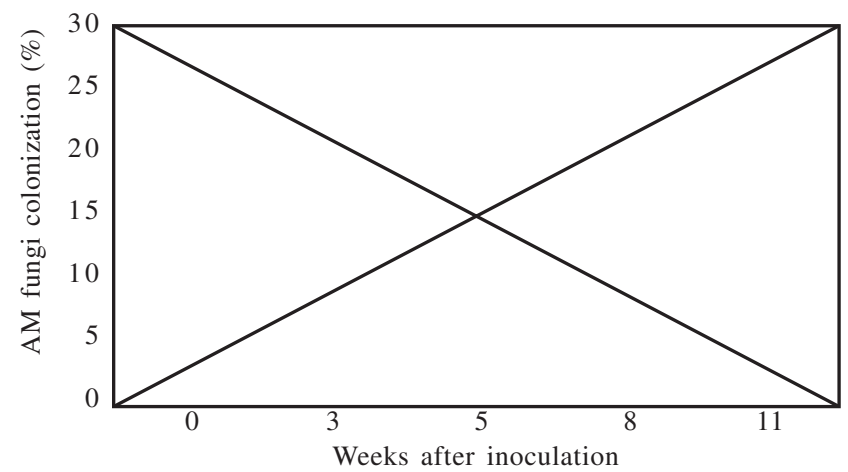

Figure 2 AM fungi colonization in secendary root of oil palm. A. tuberculata without fertilizer, A. tuberculata with fertilizer, $>$ G. margarita without fertilizer, $\square$ G. margarita with fertilizer).

weeks after inoculation is shown on Figure 3. A polypeptide with a moleculer weight of $60 \mathrm{kDa}$ was present in unfertilized plant roots, but this polypeptide was not detected in fertilized plants (Table 1). In addition, in the primary root of oil palm root inoculated with A. tuberculata and fertilized has a 26.7 $\mathrm{kDa}$ polypeptide. This polypeptide was not found in plant root inoculated with fertilizer for A. tuberculata. This result showed that probably the polypeptide was specific for $A$. tuberculata colonies in fertilized roots (Table 1).

The observation of secondary roots on the 8th week after inoculation showed that there was a $60 \mathrm{kDa}$ polypeptide found in uninoculated oil palm root given no fertilizer (Figure 4 , Table 2). The polypeptide was not found in the plant treated with fertilizer. However, there were no differences the polypeptide pattern of secondary and primary roots between inoculation with A. tuberculata and G. margarita. The same result was found in treatment with fertilizer in the two inoculated plants.

SDS PAGE analysis of secondary oil palm root at the 11th week after inoculation showed that there were no differences in polypeptide pattern of the uninoculated root between fertilized and none-fertilized plants. A $35 \mathrm{kDa}$ polypeptide was present in palm root inoculated with $A$. tuberculata that was treated with fertilizer while it is absent in the plant that were not trated with fertilizer. In addition, a $64.2 \mathrm{kDa}$ polypeptide present in secondary roots that were 


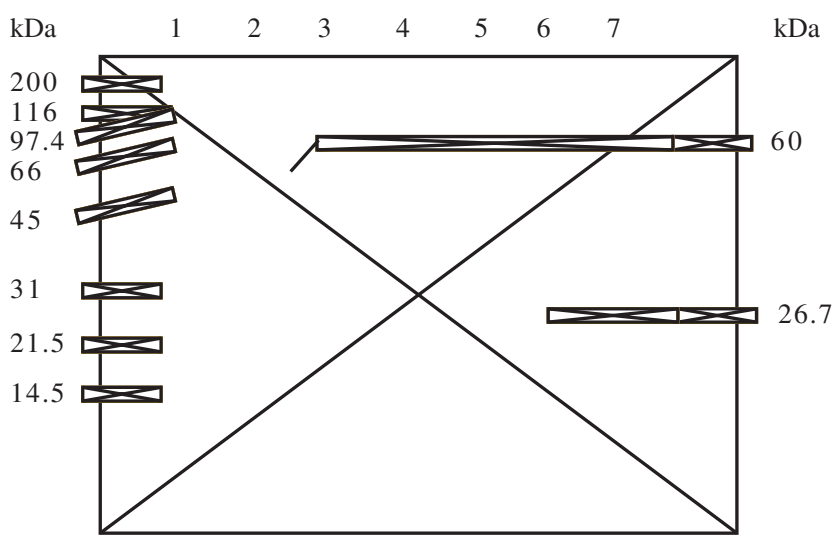

Figure 3 Silver stained SDS PAGE of primary palm root extracts 11 week after inoculation. Lane 1: Marker, 2: uninoculated without fertilizer, 3: uninoculated with fertilizer, 4: inoculated with A. tuberculata without fertilizer, 5: inoculated with A. tuberculata with fertilizer, 6: inoculated with $G$. margarita without fertilizer, 7: inoculated with G. margarita with fertilizer.

Table 1 Specific polypeptide developed at 11 week of primary oil palm root

\begin{tabular}{lc}
\hline Treatment & $\begin{array}{c}\text { Size of specific } \\
\text { polypeptide }(\mathrm{kDa})\end{array}$ \\
\hline Control: uninoculated without fertilization & 60 \\
A. tuberculata without fertilizer & 60 \\
G. margarita without fertilizer & 60 \\
A. tuberculata with fertilizer & 26.7 \\
\hline
\end{tabular}

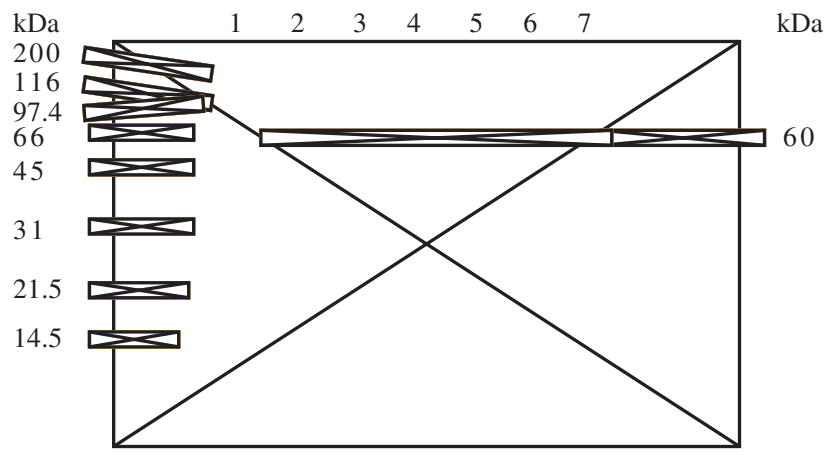

Figure 4 Silver stained SDS PAGE of secondary palm root extracts 8 week after inoculation. Lane 1: Marker, 2: uninoculated without fertilizer, 3: uninoculated with fertilizer, 4: inoculated with $A$. tuberculata without fertilizer, 5: inoculated with A. tuberculata with fertilizer, 6: inoculated G. margarita without fertilizer, 7: inoculated G. margarita with fertilizer.

Table 2 Specific polypeptide developed at eight weeks of secondary oil palm root

\begin{tabular}{lc}
\hline Treatment & $\begin{array}{c}\text { Size of specific } \\
\text { polypeptide }(\mathrm{kDa})\end{array}$ \\
\hline Control: uninoculated without fertilizer & 60 \\
A. tuberculata without fertilizer & 60 \\
G. margarita without fertilizer & 60 \\
\hline
\end{tabular}

inoculated with G. margarita although the plant was treated with fertilizer.

\section{DISCUSSION}

Infection of AM fungi in secondary roots was higher compared to primary root (Figure 1 and 2). The same result has been reported by Widiastuti et al. (2003). Based on the

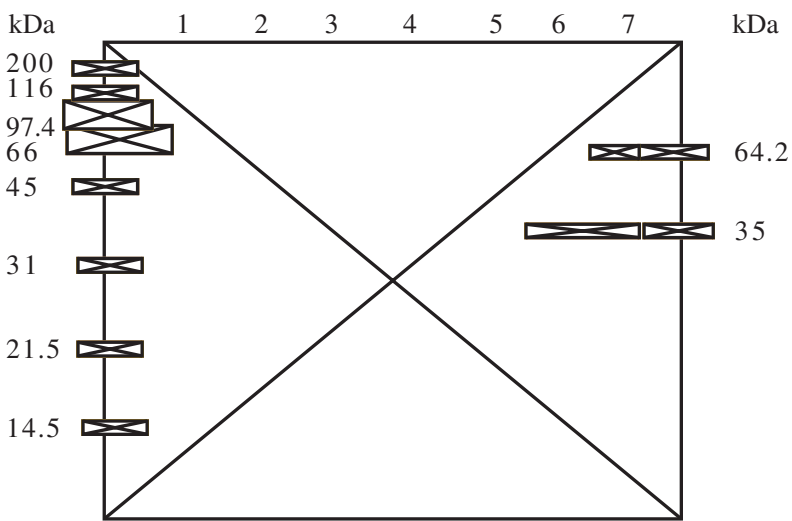

Figure 5 Silver stained SDS PAGE of secondary palm root extracts at 11th week after inoculation. Lane 1: Marker, 2: uninoculated without fertilizer, 3: uninoculated with fertilizer, 4: inoculated with A. tuberculata without fertilizer, 5: inoculated with A. tuberculata with fertilizer, 6: inoculated with G. margarita without fertilizer, 7: inoculated with G. margarita with fertilizer.

Table 3 Specific polypeptide developed at 11 week of secondary oil palm root

\begin{tabular}{lc}
\hline Treatment & $\begin{array}{c}\text { Size of specific } \\
\text { polypeptide }(\mathrm{kDa})\end{array}$ \\
\hline $\begin{array}{l}\text { A. tuberculata } \text { with fertilizer } \\
\text { G. margarita } \text { without fertilizer }\end{array}$ & 35 \\
\hline
\end{tabular}

data obtained, was conclude that infection of AM fungi first took place in secondary roots followed by infection in primary roots.

Comparasion of polypeptide pattern between primary and secondary roots showed that a $60 \mathrm{kDa}$ polypeptide was detected from primary roots of uninoculated plants without treatment with fertilizer at week 11. However, it does not in the plant that were treated with fertilizer. Similar results were found in observations at week 8 after inoculation with either A. tuberculata or G. margarita in which the $60 \mathrm{kDa}$ polypeptide was absent. The results suggested that there was a dynamic of pattern of polypeptide synthesis within oil palm roots. We suggest that the polypeptide was expressed in secondary roots in the first infection and followed by expression in primary roots. That's the infection process was took place in secondary roots first, followed by infection in primary roots.

SDS-PAGE analysis of primary roots harvested at the 11th week after inoculation with G. margarita that was not treated with fertilizer showed a specific polypeptide $(64.2 \mathrm{kDa})$. This polypeptide was also detected in secondary roots inoculated with G. margarita at week 11. This result is interesting since the same size of polypeptide was detected in two different root types within the same period. The result suggested that the response of oil palm to G. margarita inoculation both in primary and secondary root was typically the same. Detection of similar polypeptide in both primary and secondary root showed that both root types have similar protein expression.

Pacovsky (1989) showed that in soybean inoculated with Glomus fasciculatum has specific protein with the size of 16 , $17,18,22$, and $30 \mathrm{kDa}$. Samra et al. (1997) revealed that there were 12 polypeptides expressed in compatible peas. Five polypeptides were detected in the early stage of symbiosis, 
while others were observed later. It was thought that the induction and accumulation of these polypeptides seem to be more correlated to the establishment of the functional symbiosis rather than recognition stage and appresorium formation. Benabdellah et al. (2000) showed that a specific polypeptide with a size of $69 \mathrm{kDa}$ in the plasma membrane of tomato root extract inoculated with AM fungi. However, the role of the specific polypeptide detected in this research is not known. In addition, the origin of the polypeptide detected in this research is not known. It could be of fungal or plant. However, it was correlated with chitinase analysis and formation of AM fungi organs especially the arbuscle (Widiastuti 2004) it could be that the polypeptide detected in this research correlated with the final stage of recognition of symbion or early functional symbiosis. However, there was a different size of polypeptide detected in this study compared with the previously study. In this study the polypeptide was detected over a longer time (11 weeks) compared to the previously study. It seems likely that the different period of the appearance of specific polypeptide was correlated with the process of AM fungi infection. However, the differences of AM fungi species and host plant species suggested different characteristics of polypeptide and also the time of their detection.

This research also showed that the expression of several polypeptides could be detected in same period. These are shown in Figure 1, 2, and 3 both in fertilized and unfertilized oil palm and inoculated and uninoculated palm. But, from our study it is shown that the selected polypeptide was detected only in a certain period. This result in the same result as the result of Garcia-Garrido and Ocampo (2002).

In general, it has been shown that AM fungi penetration inside roots and their development in roots involved a series of morphological and physiology differentiation in both the plant and AM fungi. Comparision of polypeptide pattern isolated from mycorrhizal and non-mycorrhizal oil palm root showed that in all fractions AM colonization induced three major changes in oil palm root gene expression: up regulation and down regulation of some constitutive popypeptides already present in oil palm root and induction of some new polypeptides. This result was also shown in tomato as reported by Benabdellah et al. (2000). However, at this point in time we do not know the role of the differentially expressed polypeptides. In addition, detection of polypeptide using SDS-PAGE in one dimension is not very sensitive.
Furthermore, the polypeptide induced in the early infection was very low and differentially expressed.

\section{ACKNOWLEDGMENT}

Financial support for this study was provided by Indonesian Agency for Agriculture Research and Development, Ministry of Agriculture, Republic Indonesia through the APBN Project. The authors wished to thank Neneng and Agustiningtyas Wulandari for their excellent technical assistance.

\section{REFERENCES}

Benabdellah K, Azcon-Aguilar C, Ferrol N. 2000. Alteration in the plasma membrane polypeptide pattern of tomato roots (Lycopersicon esculentum) during the development of arbuscular mycorrhiza. J Exp Bot 51:747-754.

Bradford MM. 1976. A rapid and sensitive method for the quantification of microgram quantities of protein utilizing the principal of protein dye binding. Anal Biochem 72:248-254.

Ferrol N, Pozo MJ, Antelo M, Azcon-Aguilar C. 2002. Arbuscular mycorrhizal symbiosis regulates plasma membrane $\mathrm{H}^{+} \mathrm{ATP}$ ase gene expression in tomato plants. J Exp Bot 53:1683-1687.

Garcia-Garrido JM, Ocampo JA. 2002. Regulation of the plant defence response in arbuscular mycorrhizal symbiosis. J Exp Bot 53:13771386.

Koske RE, Gemma JN. 1989. A modified procedure for staining roots to detect VA mycorrhizas. Mycol Res 92:486-505.

Laemmli UK. 1970. Cleavage of structural proteins during the assembly of the head of bacteriphage T4. Nature 227:680-689.

Lubis AU. 1992. Kelapa Sawit (Elaeis guineensis Jacq) di Indonesia. Pusat Penelitian Perkebunan Marihat Bandar Kuala. Pematang Siantar.

Oakley BR, Kirsch DR, Morris NR. 1980. A simplified ultrasensitive silver stain for detecting proteins in polyacrylamide gels. Anal Biochem 105:361-363.

Pacovsky RS. 1989. Carbohydrate, protein and amino acid status of Glycine-Glomus-Bradyrhizobium symbioses. Physiol Plant 75:346-354.

Samra A, Dumas-Gaudot E, Gianinazzi S. 1997. Detection of symbiosisrelated polypeptides during the early stages of the establishment of arbuscular mycorrhiza between Glomus mosseae and Pisum sativum roots. New Phytol 135:711-722.

Widiastuti H. 2004. Biologi Interaksi Cendawan Mikoriza Arbuskula Kelapa Sawit pada Tanah Masam sebagai Dasar Pengembangan Teknologi Aplikasi Dini [Thesis]. Bogor: Institut Pertanian Bogor.

Widiastuti $\mathrm{H}$ et al. 2002. Optimasi simbiosis cendawan mikoriza arbuskula Acaulospora tuberculata dan Gigaspora margarita pada bibit kelapa sawit. Menara Perkebunan 70:49-56.

Widiastuti $\mathrm{H}$ et al. 2003. Arsitektur akar bibit kelapa sawit yang diinokulasi beberapa cendawan mikoriza arbuskula. Menara Perkebunan 71:26-39. 